\title{
EFFECT OF ALLOYING ELEMENTS ON THE ELECTRONIC PROPERTIES OF THIN PASSIVE FILMS FORMED ON CARBON STEEL, FERRITIC AND AUSTENITIC STAINLESS STEELS IN A HIGHLY CONCENTRATED LiBr SOLUTION
}

\author{
Fernández-Domene, R.M., Blasco-Tamarit, E., García-García, D.M., García- \\ Antón, J. * \\ Ingeniería Electroquímica y Corrosión (IEC). Departamento de Ingeniería Química y \\ Nuclear. ETSI Industriales. Universitat Politècnica de València. Camino de Vera s/n, \\ 46022 Valencia, Spain.
}

Tel.34-96-387 76 32, Fax. 34-96-387 76 39, e-mail: jgarciaa@iqn.upv.es

The influence of alloying elements on the electrochemical and semiconducting properties of thin passive films formed on several steels (carbon steel, ferritic and austenitic stainless steels) has been studied in a highly concentrated lithium bromide ( $\mathrm{LiBr}$ ) solution at $25^{\circ} \mathrm{C}$, by means of potentiodynamic tests and Mott-Schottky analysis. The addition of $\mathrm{Cr}$ to carbon steel promoted the formation of a $p$-type semiconducting region in the passive film. A high $\mathrm{Ni}$ content modified the electronic behaviour of highly alloyed austenitic stainless steels. Mo did not modify the electronic structure of the passive films, but reduced the concentration of defects.

Keywords: Carbon steel; stainless steel; thin passive films; semiconducting properties; Mott-Schottky. 


\section{INTRODUCTION}

Stainless steels are the most widely known metallic materials, and their demand has increased dramatically in recent years [1-3]. Stainless steels owe their widespread use to a combination of unique properties that have advantage over those of other steels and nonferrous metals for many applications. The main characteristics are their resistance to corrosion in different environments, their good mechanical properties over an extremely wide range of temperatures, and their resistance to oxidation and scaling at very high temperatures $[1,3]$. The corrosion resistance of stainless steels is provided by a very thin and protective surface oxide film, known as passive film. It is generally accepted that passive films formed on stainless steels have a duplex structure which consists of an inner region rich in chromium and an outer region rich in iron [4-9]. Some authors have also observed that when the amount of molybdenum in a stainless steel is high enough, it is incorporated into the passive film, showing complex oxide chemistry with different states of oxidation $[7,10,11]$. Depending on the nickel content in the stainless steel, Ni may or may not appear in the chromium and iron oxide layers $[8,9]$.

One of the main factors that control the behaviour of a passive film is its electronic properties [4-6, 12-22]. However, there is some controversy as to the electronic structure of the layers which make up the passive films formed on stainless steels, especially on those with high Ni content, and no general agreement exists on this topic yet. Some studies that used Mott-Schottky analysis [18, 19, 23-26] claimed that passive films formed on stainless steels are $n$-type semiconductors due to a protective barrier layer of $\mathrm{Cr}_{2} \mathrm{O}_{3}$; however, it is interesting to note that in the references mentioned above, only limited information has been obtained, since capacitance measurements have been 
generally restricted to the more anodic potential range. According to Sato $[12,21]$, the passive film comprises an anion-selective and $n$-type semiconductive inner layer, and a cation-selective and $p$-type semiconductive outer layer. In other studies $[4-6,17,27,28]$ the electronic structure of passive films formed on stainless steels has been described as a $p$-type inner layer (rich in Cr-species) and an $n$-type outer layer (rich in Fe-species).

Highly concentrated aqueous $\mathrm{LiBr}$ solutions are widely used as a refrigerant for absorption-type air-conditioning and industrial drying systems due to its good thermodynamic properties [29-32], but these solutions are highly corrosive and attack the copper and ferrous (austenitic and duplex stainless steels) parts of the system [3340]. Stainless steels are susceptible to several forms of localised corrosive attack, especially in the presence of halides, such as bromides. The general and localised corrosion behaviour of passive films can be related to their semiconducting properties, so it is essential to understand these semiconducting properties to correlate them with the corrosion behaviour of stainless steels. However, the interpretation of the electronic properties of passive films formed on stainless steels is difficult because of the complexity of the bilayer structure of the films. Since the alloying elements can modify the semiconducting behaviour of the different oxide layers, their influence must be taken into account when studying passive films semiconductivity, especially in highly alloyed materials.

In the present work, the influence of alloying elements on the semiconducting properties of passive films formed on several steels (carbon and stainless steels) has been studied in a highly concentrated $\mathrm{LiBr}$ solution (992 g/l, commonly used in absorption machines) at $25^{\circ} \mathrm{C}$, by means of Mott-Schottky analysis. Potentiodynamic polarisation 
experiments have also been carried out to establish a connection between the electrochemical and electronic behaviours.

\section{EXPERIMENTAL DETAILS}

\subsection{Materials, solution and electrochemical cell}

Experiments were performed in a deaerated and highly concentrated LiBr solution (992 $\mathrm{g} / \mathrm{l}, 11.42 \mathrm{M}$ ), at $25^{\circ} \mathrm{C}$. The deaerated atmosphere was created by bubbling $\mathrm{N}_{2}$ in the solution for 1 hour before the tests, and over the electrolyte solution during the tests.

The materials tested were different steels (carbon and stainless steels), with variable $\mathrm{Cr}$, Ni and Mo content (Table 1). The electrodes were cylindrically shaped (8-mm in diameter and $55 \mathrm{~mm}$ long) and covered with a polytetrafluoroethylene coating. The area exposed to the solution was $0.5 \mathrm{~cm}^{2}$. All specimens were wet abraded from 500 to 4000 $\mathrm{SiC}$ grit, and finally cleaned with ethanol, rinsed with distilled water and air-dried.

The electrochemical measurements were carried out with an Autolab PGSTAT302N potentiostat. $\mathrm{An} \mathrm{Ag} / \mathrm{AgCl}(3 \mathrm{M} \mathrm{KCl})$ electrode served as the reference electrode and a platinum wire served as the counter electrode. In all cases the tests were repeated at least three times in order to verify reproducibility.

\subsection{Potentiodynamic polarisation tests}


Potentiodynamic polarisation tests began at a potential value of $-250 \mathrm{mV}$ with respect to the open circuit potential and the potential was subsequently scanned anodically at 0.5 $\mathrm{mV} \mathrm{s}^{-1}$ until the current density reached $1 \mathrm{~mA} / \mathrm{cm}^{2}$. The pitting potential $\left(E_{p}\right)$ has been defined as the potential at which current density reaches a value of $100 \mu \mathrm{A} / \mathrm{cm}^{2}$ [40-42].

\subsection{Capacitance measurements}

Before passivation, the electrode potential was kept at a cathodic value of -800 $\mathrm{mV}_{\mathrm{Ag} / \mathrm{AgCl}}$ for 15 minutes, to create reproducible initial conditions. Afterwards, the working electrodes were polarised at the film formation potentials of $-300 \mathrm{mV}_{\mathrm{Ag} / \mathrm{AgCl}}$ for 1 hour. A film formation potential of $100 \mathrm{mV}_{\mathrm{Ag} / \mathrm{AgCl}}$ was also used in the case of Alloy 33 and Alloy 31. Capacitance measurements were performed once a stable passive film was formed on the surface of the samples. The capacitance of the interface was calculated at a constant frequency of $5 \mathrm{kHz}$ using a $10 \mathrm{mV}$ amplitude signal and scanning the potential from the formation value in the negative direction at a rate of 50 $\mathrm{mV} \mathrm{s}^{-1}$. A high scanning rate was used to avoid electroreduction of the passive film and changes in film thickness during the measurements. At a sufficiently high scanning rate, the defect structure within the passive film is "frozen-in", which avoids the defect density from being affected by potential [43-45].

\section{RESULTS AND DISCUSSION}

\subsection{Potentiodynamic polarisation curves}


Figure 1 shows the potentiodynamic polarisation curves for the six steels studied in the $992 \mathrm{~g} / \mathrm{L} \mathrm{LiBr}$ solution at $25^{\circ} \mathrm{C}$. As tests were reproducible, the curves illustrate one of the recorded measurements. A passive region where current density is almost constant is observed in all the curves. Polarisation curves also show that, once the pitting potential is reached, the current density increases sharply. The standard electrode potential of the pair $\mathrm{Br}_{2} / \mathrm{Br}^{-}\left(\mathrm{E}^{0}=882 \mathrm{mV}_{\mathrm{Ag} / \mathrm{AgCl}}\right)$ is higher than the potential values at which current density increases abruptly, so this increase indicates the breakdown of the passive film. Moreover, visual inspection of the electrodes after the potentiodynamic tests revealed clear pits throughout the samples surface.

Before the sharp increase in current density due to the onset of pitting corrosion, a slight increase in current density can be observed in the potentiodynamic polarisation curves of the different stainless steels. This steady increase of current density can be associated with the transpassive dissolution of Cr-containing species and is closely related to the passive film breakdown and localised corrosion phenomena [22].

Carbon steel S355J2G3 presents the highest values of current density within the passive region, as well as the lowest pitting potential, $E_{p}$. This displacement of the pitting potential towards more negative values makes the extent of the passive region be significantly lower for the carbon steel than for the stainless steels.

The curves of stainless steels show lower passive current densities compared with the values recorded for the carbon steel, due to the influence of $\mathrm{Cr}$ [33]. The main difference between the curves of the different stainless steels is the value of the pitting potential. The value of the pitting potential is affected by several parameters, such as 
temperature, concentration of aggressive ions or alloy composition. In this case, the differences in $E_{p}$ between stainless steels are caused by the alloying elements. When alloying the carbon steel with 17 wt.\% Cr (AISI 430), the pitting potential increases dramatically. Therefore, the positive influence of $\mathrm{Cr}$ on the pitting corrosion resistance of stainless steels is evident from Figure 1, due to the formation of $\mathrm{Cr}$ (III) oxides and hydroxides. The addition of $10 \mathrm{wt} \% \mathrm{Ni}$ (AISI 304) modifies the value of $E_{p}$ to some extent, whereas the addition of 2.3 wt.\% Mo (AISI 316) has a more clear influence. Finally, a considerable increase in $\mathrm{Cr}$ and $\mathrm{Ni}$ content (Alloy 33) as well as in Mo content (Alloy 31) enhances the resistance to pitting corrosion even more. The main influence of $\mathrm{Ni}$ in the curves shown in Figure 1 is the reduction of the passive current density, which decreases for AISI 304 if compared with AISI 430. It can also be observed that Mo enhances the passivity of AISI 316 in comparison with AISI 304, and Alloy 31 in comparison with Alloy 33, shifting the pitting potential towards more positive values, having therefore a beneficial influence on the pitting resistance of stainless steels, as also reported by other authors [10, 36, 46-48].

The relative resistance of a stainless steel to pitting corrosion in the presence of aggressive anions, such as bromides, can be related to an alloy composition by an empirical formula called the Pitting Resistance Equivalent Number (PREN). The most commonly used PREN expression is [49]:

$$
\mathrm{PREN}=\% \mathrm{Cr}+3.3[\% \mathrm{Mo}+0.5 \% \mathrm{~W}]+x . \% \mathrm{~N}
$$


where the multiplier $x$ is typically given as 30, and composition is weight percent. In general, the larger the numerical value of PREN, the higher the pitting corrosion resistance.

Table 2 shows the values of the pitting potential, $E_{p}$, and PREN for the six steels studied in this work. It can be seen that $E_{p}$ increases with increasing PREN values. A PREN value of 33 or higher is considered necessary for pitting resistance to aggressive environments, such as seawater [2].

\subsection{Capacitance measurements}

Oxide films with perfect crystal structures can be considered as insulators provided they are stoichiometric. However, the presence of point defects in the structure of passive films makes these oxide films behave as extrinsic semiconductors when exposed to an aqueous solution. The main point defects are cation vacancies $\left(\mathrm{V}_{\mathrm{M}}{ }^{\chi^{\prime}}\right)$, anion vacancies (oxygen vacancies, $\mathrm{V}_{\mathrm{O}}^{\bullet}$ ) and/or cation interstitials, $\mathrm{M}_{\mathrm{i}}^{\chi^{+}}$. Kroger-Vink notation is used for the effective positive $\left({ }^{*}\right)$ and negative $\left({ }^{\prime}\right)$ charges in oxygen and cation vacancies, respectively. The extrinsic semiconducting behaviour of these passive films can be $n$ type and/or $p$-type, depending on the relative number of defects within the film $[17,18$, $26,28,50-55]$. Thus, a predominance of cation vacancies over oxygen vacancies and/or cation interstitials leads to $p$-type semiconductivity, while the opposite situation leads to $n$-type semiconductivity.

The capacitance of the passive film/electrolyte interface, $C$, can be described by a MottSchottky relationship. Taking into account the capacitance of the Helmholtz layer and 
neglecting the Guoy-Chapman diffuse layer and surface states contribution for the total capacitance, this relationship becomes $[4,22]$ :

$$
\frac{1}{C^{2}}=\frac{1}{C_{S C}^{2}}+\frac{1}{C_{H}^{2}}+\frac{2}{C_{S C} C_{H}}
$$

where $C_{S C}$ is the capacitance of the space charge layer and $C_{H}$ the capacitance of the Helmholtz layer. Eq. (2) can be expanded to distinguish between $n$-type and $p$-type semiconductors:

$$
\begin{array}{ll}
\frac{1}{C^{2}}=\frac{1}{C_{H}^{2}}+\frac{2}{\varepsilon \varepsilon_{0} e N_{D}}\left(E-E_{F B}-\frac{k T}{e}\right) & \text { n-type } \\
\frac{1}{C^{2}}=\frac{1}{C_{H}^{2}}-\frac{2}{\varepsilon \varepsilon_{0} e N_{A}}\left(E-E_{F B}-\frac{k T}{e}\right) & p \text {-type }
\end{array}
$$

where $\varepsilon$ represents the dielectric constant of the passive film (values of $12[56,57]$ and $15.6[4,5,13]$ have been assumed for the oxides formed on carbon steel and stainless steels, respectively), $\varepsilon_{0}$ is the vacuum permittivity $\left(8.85 \cdot 10^{-14} \mathrm{~F} / \mathrm{cm}\right), e$ is the electron charge $\left(1.60 \cdot 10^{-19} \mathrm{C}\right), N_{D}$ and $N_{A}$ are the donor and acceptor densities, respectively, $E_{F B}$ is the flat-band potential, $k$ is the Boltzmann constant $\left(1.38 \cdot 10^{-23} \mathrm{~J} / \mathrm{K}\right)$ and $T$ is the absolute temperature.

As it has been mentioned in the experimental procedure section, capacitance measurements were performed at $5 \mathrm{kHz}$, since it has been demonstrated in a previous work [22] that capacitance becomes independent of frequency at approximately $5 \mathrm{kHz}$ 
for stainless steels in heavy brine $\mathrm{LiBr}$ solutions. Figure 2a shows the Mott-Schottky plots for the films formed on the six steels at the passive potential of $-300 \mathrm{mV}$. To better observe the Mott-Schottky plots, Figure 2b shows the $C^{-2}$ vs. $E$ representations for the steels with lower alloy element content (carbon steel, AISI 430, AISI 304 and AISI 316). Figure 2c shows the Mott-Schottky plots of Alloy 33 and Alloy 31 obtained at two different passive potentials: -300 and $100 \mathrm{mV}$. In general, plots reveal the presence of two linear regions at low and high potentials. In the region at $E>-0.65 \mathrm{~V}$, approximately, straight lines with positive slopes can be observed, indicating that capacitance represents the electrochemical behaviour of an $n$-type semiconductor, according to eq. (3a). In the more cathodic region ( $E<-0.65 \mathrm{~V}$, approximately), there are straight lines with negative slopes, so the capacitance describes the behaviour of a $p$ type semiconductor, according to eq. (3b).

The values of the density of defects (donor and acceptor species, $N_{D}$ and $N_{A}$, respectively) within the passive films formed on the six steels at a given potential can be calculated from the positive and negative slopes of the linear zones in Mott-Schottky plots (Figure 2), using equations (3a) and (3b), respectively. Table 3 shows the values of $N_{D}$ and $N_{A}$ at film formation potentials of $-300 \mathrm{mV}$ and $100 \mathrm{mV}$ (the latter only for Alloys 33 and 31).

\subsubsection{Carbon steel}

Carbon steel S355J2G3 does not present $p$-type semiconductivity since only one linear region with positive slope can be observed in Figure $\mathbf{2 b}$, indicating an $n$-type semiconducting behaviour. Passive films formed on carbon steels have a similar 
composition than those formed on iron with an inverse spinel structure related to both $\gamma-\mathrm{Fe}_{2} \mathrm{O}_{3}$ and $\mathrm{Fe}_{3} \mathrm{O}_{4}$ [56-59]. Thermodynamically, $\mathrm{Fe}_{2} \mathrm{O}_{3}$ is the most stable species at the experimental conditions [33] and the capacitance behaviour would be controlled by the electronic structure of $\mathrm{Fe}_{2} \mathrm{O}_{3}$ in the passive film, which explains the presence of the straight line with positive slope in the Mott-Schottky plot. In $n$-type semiconducting passive films, the predominant donor species are oxygen vacancies, $\mathrm{V}_{\mathrm{O}}^{\bullet \bullet}$ and/or cation interstitials, $\mathrm{Fe}_{\mathrm{i}}^{\chi^{+}}$.

At $-300 \mathrm{mV}, N_{D}$ is very high for the carbon steel (Table 3), which indicates a highly disordered nature of its passive film and low protective properties in concentrated $\mathrm{LiBr}$ media.

\subsubsection{AISI 430, 304 and 316}

The influence of chromium on the capacitance behaviour of stainless steels can be determined by observing the Mott-Schottky plot for AISI 430 (Figura 2b). This plot reveals the existence of two straight lines below and above a potential of about $-0.65 \mathrm{~V}$ (the flat-band potential, $E_{F B}$ ). Thus, the addition of $17 \mathrm{wt} . \% \mathrm{Cr}$ to carbon steel promotes the formation of a $p$-type semiconductivity region in the passive film. This $p$-type region can also be observed in the Mott-Schottky plots for AISI 304 and AISI 316. Many analytical studies [4-9] have revealed that passive films formed on stainless steels have, at least, a duplex structure which consists of an inner region rich in $\mathrm{Cr}$ and an outer layer rich in Fe. The significant enrichment of chromium species within the inner layer of the passive film can be explained by the preferential oxidation of $\mathrm{Cr}$ prior to the

onset of Fe oxidation [60]. Besides, the location of each alloying component within the 
passive film depends on their mobility through the film [60, 61]. Therefore, faster diffusing components will pass through to the outer layer, such as Fe cations, while slower diffusing components like $\mathrm{Cr}$ cations will be oxidized without movement and remain in the inner region of the passive film. Therefore, the $p$-type region observed in Figure $2 \mathbf{b}$ for the three stainless steels with $17-18$ wt.\% $\mathrm{Cr}$ seems to be related to the inner layer of the passive film, while the $n$-type could be attributed to the electrochemical behaviour of the outer layer.

The bilayer structure of passive films formed on stainless steels has shown to be more complex $[8,10,14,17,27,62,63]$. In ferritic and austenitic stainless steels with less than $10-12$ wt.\% $\mathrm{Ni}$, the outer region of the passive film is made up of a layer of $\mathrm{Cr}$ and Fe hydroxides, oxy-hydroxides and $\mathrm{Fe}_{2} \mathrm{O}_{3}$ [14], with $n$-type semiconductivity [63, 64]. The hydroxides and oxy-hydroxides present in the outer layer of the film form via precipitation from hydrolysis of metal cations and can incorporate other species from solution (e.g. $\left.\mathrm{Br}^{-}\right)[50,52,53,65]$. The inner layer consists of an oxide $\mathrm{Fe}-\mathrm{Cr}$ spinel whose general structure can be written as $\mathrm{Fe}(\mathrm{II})\left[\mathrm{Cr}(\mathrm{III})_{\mathrm{x}} \mathrm{Fe}(\mathrm{III})_{(1-\mathrm{x})}\right]_{2} \mathrm{O}_{4}$, where $0<x \leq 1$ [14]. Normal spinels, such as $\mathrm{FeCr}_{2} \mathrm{O}_{4}$, have the general formula $\mathrm{AB}_{2} \mathrm{O}_{4}$, where the divalent A-cations are occupying 1/8 of the tetrahedral holes and the trivalent B-cations are occupying $1 / 2$ of the octahedral holes. In inverse spinels, which have the general formula $\mathrm{B}[\mathrm{AB}] \mathrm{O}_{4}$, the trivalent $\mathrm{B}$-cations are occupying $1 / 8$ of the tetrahedral holes and the second divalent B- and trivalent A-cations are occupying 1/2 of the octahedral holes.

It has been observed [14] that the mixed Fe-Cr oxide with spinel structure can act as both an $n$-type and a $p$-type semiconductor due to the influence of different donor and acceptor species, respectively. Making $x=1$, the general formula of the spinel can be 
simplified as $\mathrm{FeCr}_{2} \mathrm{O}_{4}$ (chromite, with the tetrahedral and octahedral sites occupied by $\mathrm{Fe}(\mathrm{II})$ and $\mathrm{Cr}(\mathrm{III})$ cations, respectively), which is known to have deficiency of cations [66] and, therefore, behaves as a $p$-type semiconductor $[63,66]$. On the other hand, with $x \rightarrow 0$, the formula of the spinel approaches that of $\mathrm{Fe}_{3} \mathrm{O}_{4}$ (magnetite, which is an inverse spinel where all the Fe(II) cations occupy the octahedral sites and Fe(III) cations occupy tetrahedral and octahedral sites evenly). Inverse spinels, such as $\mathrm{Fe}_{3} \mathrm{O}_{4}, \mathrm{NiFe}_{2} \mathrm{O}_{4}$ or $\mathrm{MgFe}_{2} \mathrm{O}_{4}$, are normally $n$-type semiconductors [66, 67]. Therefore, an increase of $\mathrm{Cr}(\mathrm{III})$ in the spinel structure will favour $p$-type semiconductivity. As mentioned above, it is widely accepted that there is an enrichment of $\mathrm{Cr}$ in the inner region of passive films formed on stainless steels [4-9], accordingly the $p$-type region observed in Figure 2b should be related to the inner part of the passive film close to the metal surface. According to the previous explanations and the capacitance results, the passive film formed on AISI 430 consists of an inner layer of anhydrous mixed Fe-Cr oxide with a spinel structure which behaves as a p-type semiconductor (rich in $\mathrm{Cr}$ ) in the region close to the metal surface and as an $n$-type semiconductor (rich in $\mathrm{Fe}$ ) in the region close to the outer layer of the film. This outer layer is made up of $\mathrm{Cr}$ and Fe hydroxides, oxyhydroxides and $\mathrm{Fe}_{2} \mathrm{O}_{3}$ with $n$-type semiconducting behaviour.

Regarding the influence of $\mathrm{Ni}$ on the semiconducting behaviour of AISI 304 and AISI 316 , some authors have reported $[7,8,68,69]$ that the Ni content of the passive film formed on conventional austenitic stainless steels was very low or non-existent. It can be observed in Figure 2b that the capacitance behaviour of AISI 430 and AISI 304 is very similar, as well as the values of $N_{A}$ and $N_{D}$ (Table 3). Thus, the Mott-Schottky plot of AISI 304 shows the behaviour of the bilayer passive film described previously for AISI 430. 
The addition of 2.3 wt.\% Mo does not modify the electronic structure of the passive film formed on AISI 316 (Figure 2b), although it has a positive influence, decreasing the capacitance values, especially in the $n$-type region. For AISI 316, the value of $N_{A}$ remains almost constant but $N_{D}$ decreased with respect to the values obtained for AISI 430 and 304 (Table 3). The decrease in donor density has been observed in the literature when alloying austenitic stainless steels with Mo $[6,48,70]$. Mo(VI) has been found to be enriched at the surface of the passive film $[10,11]$, whereas $\operatorname{Mo}(\mathrm{IV})$ species are distributed more homogeneously through the film [10] or associated with the inner layer [11]. The positive sign of oxygen vacancies and/or cation interstitials is cancelled by the action of $\mathrm{MoO}_{4}{ }^{2-}$ ions $[6,48,70]$. Besides, $\mathrm{Mo}^{4+}$ and $\mathrm{Mo}^{6+}$ cause excessive positive charge, reducing the concentration of positive donors to satisfy the charge neutrality in the film [48].

\subsubsection{Alloy 33 and Alloy 31}

The Mott-Schottky plots of the highly alloyed austenitic stainless steels Alloy 33 and Alloy 31 (Figure 2a) reveal the existence of a very clear $n$-type region with very low capacitance values, and a less marked $p$-type region, which completely disappears in the case of Alloy 31, in spite of the high Cr content of both alloys. Therefore, the considerable increase in $\mathrm{Cr}$ and $\mathrm{Ni}$ content in Alloy 33 and Alloy 31 visibly enhances the $n$-type semiconductivity but makes the $p$-type region difficult to discern, especially for Alloy 31.

It has been commented above that $\mathrm{Ni}$ has not been found in the passive film of conventional austenitic stainless steels. However, if the Ni content in the alloy is high 
enough, as in Alloys 33 and $31(\mathrm{Ni}>30 \mathrm{wt} . \%)$, it may be found in the film [8, 36, 64]. It has been reported that high $\mathrm{Ni}$ stainless steels and nickel-based alloys have a much larger $\mathrm{Ni} / \mathrm{Fe}$ ratio in their passive films than conventional austenitic stainless steels [8, 61, 64, 71-73]. Ni has been detected in the inner region, as well as in the intermediate and outer parts of the film $[8,61,72,73]$. Several authors, working with highly alloyed stainless steels and nickel-base alloys, have suggested the formation of a ternary Fe-CrNi oxide layer with spinel structure in the passive film $[5,64,73]$. Pourbaix diagrams for the ternary system Fe-Cr-Ni $[66,74]$ show that four spinel oxides can coexist in equilibrium with the aqueous solution $\left(\mathrm{Fe}_{3} \mathrm{O}_{4}, \mathrm{NiFe}_{2} \mathrm{O}_{4}, \mathrm{FeCr}_{2} \mathrm{O}_{4}\right.$ and $\left.\mathrm{NiCr}_{2} \mathrm{O}_{4}\right)$. In a similar way to the general formula presented above for the binary $\mathrm{Fe}-\mathrm{Cr}$ spinel, the general structure of the Fe-Cr-Ni spinel can be written as $\mathrm{Ni}(\mathrm{II})\left[\mathrm{Fe}(\mathrm{III})_{\mathrm{y}} \mathrm{Cr}(\mathrm{III})_{(1-\mathrm{y})}\right]_{2} \mathrm{O}_{4}$, with $0<y \leq 1$. In the region close to the metal surface, the spinel oxide would be rich in $\mathrm{Cr}$ and its properties would resemble those of $\mathrm{NiCr}_{2} \mathrm{O}_{4}$ (nickel chromite), which is a normal spinel and behaves as a p-type semiconductor [73]. As the Cr content in the passive film decreases near the outer hydroxide layer of the film, the spinel structure will change gradually from $\mathrm{NiCr}_{2} \mathrm{O}_{4}$ to $\mathrm{NiFe}_{2} \mathrm{O}_{4}$ (trevorite), which has an inverse structure and behaves as an $n$-type semiconductor $[66,67,73,75,76]$. In fact, the $\mathrm{NiFe}_{2} \mathrm{O}_{4}$ spinel is more stable than a mixture of iron oxides and/or hydroxides $\left(\mathrm{Fe}_{3} \mathrm{O}_{4}\right.$, $\mathrm{Fe}_{2} \mathrm{O}_{3}$ or $\left.\mathrm{Fe}(\mathrm{OH})_{3}\right)[66,74]$.

According to the previous description, the Mott-Schottky plots of Alloy 33 and Alloy 31 should clearly show both a $p$-type and an $n$-type behaviour, like in the plots obtained for AISI 430, 304 and 316. Nevertheless, the Mott-Schottky plots of the high Ni austenitic stainless steels, especially Alloy 31, (Figure 2a) do not show a clear $p$-type region. This fact can be explained by the influence of film formation potential on the 
stability of the different spinel oxides, which has not been considered in the description given above. Although the $\mathrm{NiCr}_{2} \mathrm{O}_{4}$ spinel can be an equilibrium solid phase [66, 74], its stability field is often limited at high potentials [66].

In order to study the influence of the film formation potential on the semiconducting properties of Alloys 33 and 31, the Mott-Schottky plots of the passive films formed on these two alloys at two passive potentials (low passive potential, $-300 \mathrm{mV}$, and high passive potential, $100 \mathrm{mV}$ ) are shown in Figure 2c. The $p$-type region is much more marked at $100 \mathrm{mV}$ than at $-300 \mathrm{mV}$. It has been reported in literature [73, 77-81] that the concentration of $\mathrm{Cr}(\mathrm{III})$ in the passive films formed on stainless steels, $\mathrm{Ni}-\mathrm{Cr}$ alloys and pure $\mathrm{Cr}$ increases with increasing formation potential within the passive region.

In a recent study [22] it has been determined that there is a preponderance of cation vacancies over cation interstitials and oxygen vacancies in the passive films formed on Alloy 31 in a heavy brine $\mathrm{LiBr}$ solution $(700 \mathrm{~g} / \mathrm{l})$. In fact, the slight or nonexistent $p$ type behaviour obtained for Alloy 33 and Alloy 31 at $-300 \mathrm{mV}$ (Figures $2 \mathbf{b}$ and $\mathbf{2 c}$ ) indicates that there is a high deficiency of cations in the region close to the metal surface and the spinel oxide in that region behaves as a highly degenerate semiconductor. Therefore, due to the high concentration of cation vacancies the spinel oxide no longer behaves as a $p$-type semiconductor but as a metal-like conductor. Thus, the presence of the $p$-type region in the Mott-Schottky plots shown in Figure 2c at the formation potential of $100 \mathrm{mV}$ is probably related to the increase in $\mathrm{Cr}(\mathrm{III})$, which implies a decrease in the number of cation vacancies, $\mathrm{V}_{\mathrm{Cr}}{ }^{3}$, and the formation of the spinel $\mathrm{NiCr}_{2} \mathrm{O}_{4}$ near the metal surface, which displays $p$-type semiconductivity [73]. 
For Alloy 33, the donor density $N_{D}$ decreases significantly compared with the conventional ferritic and austenitic stainless steels used in this work (Table 3), whereas there is an increase in the value of $N_{A}$ (cation vacancy density cannot be determined for Alloy 31 , since at $-300 \mathrm{mV}$ the passive film does not show $p$-type semiconducting behaviour). At $100 \mathrm{mV}$, it can be observed that $N_{D}$ for Alloys 33 and 31 remains approximately constant, while $N_{A}$ decreases significantly. This decrease is a consequence of an increase in the concentration of $\mathrm{Cr}(\mathrm{III})$ oxide within the passive film, which in turn leads to a decrease in the number of cation vacancies, $\mathrm{V}_{\mathrm{Cr}}{ }^{3}$, as explained above.

Concerning the influence of Mo at concentrations higher than $5 \mathrm{wt} \%$, it can be observed in Figures 2a and $\mathbf{2} \mathbf{c}$ that capacitance values in the $n$-type region are lower for Alloy 31 than for Alloy 33, indicating a thicker and more protective passive film. Thus, the lowest value of $N_{D}$ obtained for Alloy 31 (Table 3) can be related to the effect of Mo species. As it has been explained above for AISI 316, the decrease in $N_{D}$ is related to the presence of $\mathrm{MoO}_{4}{ }^{2-}, \mathrm{Mo}^{4+}$ and $\mathrm{Mo}^{6+}$, which neutralise or inhibit the formation of the positive donors (oxygen vacancies and/or metal interstitials). Other authors [82] suggest that $\mathrm{Mo}(\mathrm{VI})$ species, when present in the film, electrostatically interact with negatively charged cation vacancies to reduce their flux from the film/solution interface to the metal/film interface, making the condensation of vacancies more difficult.

On the other hand, some authors have associated the absence of $p$-type semiconductivity of passive films formed on high Mo stainless steels with the formation of Mo compounds in the inner layer of the passive film, such as $\mathrm{MoO}_{3}[20,83]$ which acts as an $n$-type semiconductor [20,63]. 
According to the obtained results, the inner layer of the passive films formed on Alloys 33 and 31 at low passive potentials shows slight or non-existent $p$-type semiconductivity due to the formation of a highly defective $\mathrm{Fe}-\mathrm{Cr}-\mathrm{Ni}$ spinel with a large concentration of cation vacancies $\left(\mathrm{V}_{\mathrm{Cr}}^{3^{\prime}}\right)$ and $n$-type semiconductivity due to the formation of an anhydrous mixed Fe-Cr-Ni spinel oxide enriched in Fe. At high passive potentials, the inner layer of the film displays $p$ - $n$ semiconductivity, the $p$-type semiconductivity being associated with the Cr-enriched Fe-Cr-Ni spinel formed near the metal surface and the $n$-type behaviour with the Fe-enriched Fe-Cr-Ni spinel formed near the outer layer of the film. The outer layer of the passive film, which exhibits $n$-type semiconductivity too, consists of a mixture of $\mathrm{Cr}$ and $\mathrm{Fe}$ hydroxides and oxyhydroxides, as in the case of AISI 430, 304 and 316. Mo species can also be present in the passive film formed on Alloy 31.

A summary of the composition and electronic structure of the passive films formed on the different stainless steels is shown schematically in Figure 3. In AISI 316 and Alloy 31, Mo species can also be present in the passive films. Note that the different layers are not in scale.

\section{CONCLUSIONS}

The pitting potential was found to increase dramatically with chromium contents

$>17 \mathrm{wt} \%$, whereas molybdenum is effective at minor concentrations of $2-6 \mathrm{wt} \%$. $\mathrm{Ni}$ does not have a significant influence on the passive behaviour of stainless steels, but reduces the passive current density of AISI 304 when compared with AISI 430. 
Capacitance results indicate that the passive film formed on AISI 430 and AISI 304 consists of an inner layer of anhydrous mixed Fe-Cr oxide with a spinel structure which behaves as a $p$-type semiconductor (enriched in $\mathrm{Cr}$ ) in the region close to the metal surface and as an $n$-type semiconductor (enriched in $\mathrm{Fe}$ ) in the region close to the outer layer of the film, which is in turn made up of $\mathrm{Cr}$ and Fe hydroxides, oxy-hydroxides and $\mathrm{Fe}_{2} \mathrm{O}_{3}$ with $n$-type semiconducting behaviour. The presence of 2.3 wt.\% Mo does not modify the electronic structure of the passive film formed on AISI 316, but decreases capacitance values.

The slight or non-existent $p$-type behaviour of the passive films formed on high $\mathrm{Ni}$ austenitic stainless steels (Alloy 33 and Alloy 31) at low passive potentials indicates that there is a high deficiency of cations in the region close to the metal surface. Therefore, the oxide spinel in that region behaves as a highly degenerate semiconductor and starts to act as a metal-like conductor. At higher passive potentials, there is an increase in $\mathrm{Cr}$ (III) in the passive film, resulting in a decrease in the number of cation vacancies, $\mathrm{V}_{\mathrm{Cr}}^{3^{\prime}}$, and the formation of the spinel $\mathrm{NiCr}_{2} \mathrm{O}_{4}$ near the metal surface, which displays $p$-type semiconductivity.

A decrease in $N_{D}$ has been observed in presence of Mo (AISI 316 and Alloy 31), which can be related to the presence of $\mathrm{MoO}_{4}{ }^{2-}, \mathrm{Mo}^{4+}$ and $\mathrm{Mo}^{6+}$. These species neutralise or inhibit the formation of the positive donors (oxygen vacancies and/or metal interstitials).

\section{ACKNOWLEDGEMENTS}


We wish express our gratitude to the Ministerio de Ciencia e Innovación (Project CTQ2009-07518), for the economical support of this research, to Thyssen Krupp for supplying the materials, and to Dr. M. Asunción Jaime for her translation assistance.

\section{REFERENCES}

[1] Harold M.Cobb (Ed.), Steel Products Manual: Stainless Steels, Iron \& Steel Society, 1999.

[2] P. A. Schweitzer, Corrosion Engineering Handbook: Fundamentals of Metallic Corrosion, CRC Press, Boca Ratón, FL., 2007.

[3] A. J. Sedriks, Corrosion Resistance of Stainless Steels and Nickel Alloys, in: S.D. Cramer, B.S. Covino, Jr. (Eds.), Corrosion: Fundamentals, Testing and Protection, Vol. 13A, ASM Handbook, in: 2003, 697-702.

[4] N. E. Hakiki, S. Boudin, B. Rondot, M. Da Cunha Belo. The electronic structure of passive films formed on stainless steels, Corros. Sci. 37 (1995) 1809-1822.

[5] T. L. S. Wijesinghe, D. J. Blackwood. Photocurrent and capacitance investigations into the nature of the passive films on austenitic stainless steels, Corros. Sci. 50 (2008) 23-34.

[6] N. E. Hakiki, M. Da Cunha Belo, A. M. P. Simoes, M. G. S. Ferreira. Semiconducting Properties of Passive Films Formed on Stainless Steels, J. Electrochem. Soc. 145 (1998) 3821-3829.

[7] I. Olefjord, B. Brox, U. Jelvestam. Surface Composition of Stainless Steels during Anodic Dissolution and Passivation Studied by ESCA, J. Electrochem. Soc. 132 (1985) 2854-2861.

[8] G. Lothongkum, S. Chaikittisilp, A. W. Lothongkum. XPS investigation of surface films on high Cr-Ni ferritic and austenitic stainless steels, Appl. Surf. Sci. 218 (2003) 203-210.

[9] L. Freire, M. J. Carmezim, M. G. S. Ferreira, M. F. Montemor. The passive behaviour of AISI 316 in alkaline media and the effect of $\mathrm{pH}$ : A combined electrochemical and analytical study, Electrochim. Acta 55 (2010) 6174-6181.

[10] C.-O. A. Olsson, D. Landolt. Passive films on stainless steels--chemistry, structure and growth, Electrochim. Acta 48 (2003) 1093-1104.

[11] C. T. Liu, J. K. Wu. Influence of $\mathrm{pH}$ on the passivation behavior of 254SMO stainless steel in 3.5\% NaCl solution, Corros. Sci. 49 (2007) 2198-2209. 
[12] N. Sato. An overview on the passivity of metals, Corros. Sci. 31 (1990) 1-19.

[13] A. D. Paola. Semiconducting properties of passive films on stainless steels, Electrochim. Acta 34 (1989) 203-210.

[14] T. L. S. Wijesinghe, D. J. Blackwood. Characterisation of passive films on 300 series stainless steels, Appl. Surf. Sci. 253 (2006) 1006-1009.

[15] Y. F. Cheng, J. L. Luo. Electronic structure and pitting susceptibility of passive film on carbon steel, Electrochim. Acta 44 (1999) 2947-2957.

[16] H. Tsuchiya, S. Fujimoto, O. Chihara, T. Shibata. Semiconductive behavior of passive films formed on pure $\mathrm{Cr}$ and $\mathrm{Fe}-\mathrm{Cr}$ alloys in sulfuric acid solution, Electrochim. Acta 47 (2002) 4357-4366.

[17] S. Ningshen, U. Kamachi Mudali, V. K. Mittal, H. S. Khatak. Semiconducting and passive film properties of nitrogen-containing type 316LN stainless steels, Corros. Sci. 49 (2007) 481-496.

[18] M. V. Cardoso, S. T. Amaral, E. M. A. Martini. Temperature effect in the corrosion resistance of Ni-Fe-Cr alloy in chloride medium, Corros. Sci. 50 (2008) 2429-2436.

[19] A. Fattah-alhosseini, F. Soltani, F. Shirsalimi, B. Ezadi, N. Attarzadeh. The semiconducting properties of passive films formed on AISI $316 \mathrm{~L}$ and AISI 321 stainless steels: A test of the point defect model (PDM), Corros. Sci. 53 (2011) 3186-3192.

[20] C. Escrivà-Cerdán, E. Blasco-Tamarit, D. M. García-García, J. García-Antón, A. Guenbour. Effect of potential formation on the electrochemical behaviour of a highly alloyed austenitic stainless steel in contaminated phosphoric acid at different temperatures, Electrochim. Acta 80 (2012) 248-256.

[21] N. Sato. Toward a More Fundamental Understanding of Corrosion Processes, CORROSION 45 (1989) 354-368.

[22] R. M. Fernández-Domene, E. Blasco-Tamarit, D. M. García-García, J. GarcíaAntón. Passive and Transpassive Behaviour of Alloy 31 in a Heavy Brine Libr Solution, Electrochim. Acta 95 (2013) 1-11.

[23] H. Tsuchiya, S. Fujimoto, T. Shibata. Semiconductive behavior of passive films formed on Fe-Cr alloy, J. Electroceram. 16 (2006) 49-54.

[24] I. Nicic, D. D. Macdonald. The passivity of Type 316L stainless steel in borate buffer solution, J. Nucl. Mater. 379 (2008) 54-58.

[25] Y. Zhang, M. Urquidi-Macdonald, G. R. Engelhardt, D. D. Macdonald. Development of localized corrosion damage on low pressure turbine disks and blades: I. Passivity, Electrochim. Acta 69 (2012) 1-11. 
[26] A. Fattah-alhosseini, M. A. Golozar, A. Saatchi, K. Raeissi. Effect of solution concentration on semiconducting properties of passive films formed on austenitic stainless steels, Corros. Sci. 52 (2010) 205-209.

[27] M. Da Cunha Belo, B. Rondot, C. Compere, M. F. Montemor, A. M. P. Simoes, M. G. S. Ferreira. Chemical composition and semiconducting behaviour of stainless steel passive films in contact with artificial seawater, Corros. Sci. 40 (1998) 481-494.

[28] M. Metikos-Hukovic, R. Babic, Z. Grubac, Z. Petrovic, N. Lajçi. High corrosion resistance of austenitic stainless steel alloyed with nitrogen in an acid solution, Corros. Sci. 53 (2011) 2176-2183.

[29] R. J. Lee, R. M. DiGuilio, S. M. Jeter, A. S. Teja. Properties of Lithium Bromide-Water Solutions at High Temperatures and Concentrations- II: Density and Viscosity, ASHRAE Trans. 96 (1990) .

[30] G. A. Florides, S. A. Kalogirou, S. A. Tassou, L. C. Wrobel. Design and construction of a LiBr-water absorption machine, Energy Convers. Manag. 44 (2003) 2483-2508.

[31] R. D. Misra, P. K. Sahoo, A. Gupta. Thermoeconomic evaluation and optimization of a double-effect $\mathrm{H} 2 \mathrm{O} / \mathrm{LiBr}$ vapour-absorption refrigeration system, Int. J. Refrig. 28 (2005) 331-343.

[32] S. Popli, P. Rodgers, V. Eveloy. Gas turbine efficiency enhancement using waste heat powered absorption chillers in the oil and gas industry, Appl. Therm. Eng. 50 (2013) 918-931.

[33] J. L. Guiñón, J. García-Antón, V. Pérez-Herranz, G. Lacoste. Corrosion of Carbon Steels, Stainless Steels, and Titanium in Aqueous Lithium Bromide Solution, CORROSION 50 (1994) 240-246.

[34] A. Igual-Muñoz, J. García-Antón, S. López Nuévalos, J. L. Guiñón, V. PérezHerranz. Corrosion studies of austenitic and duplex stainless steels in aqueous lithium bromide solution at different temperatures, Corros. Sci. 46 (2004) 2955-2974.

[35] D. M. García-García, J. García-Antón, A. Igual-Muñoz, E. Blasco-Tamarit. Effect of cavitation on the corrosion behaviour of welded and non-welded duplex stainless steel in aqueous LiBr solutions, Corros. Sci. 48 (2006) 23802405.

[36] E. Blasco-Tamarit, A. Igual-Muñoz, J. García-Antón, D. M. García-García. Effect of aqueous $\mathrm{LiBr}$ solutions on the corrosion resistance and galvanic corrosion of an austenitic stainless steel in its welded and non-welded condition, Corros. Sci. 48 (2006) 863-886.

[37] R. Sánchez-Tovar, M. T. Montañés, J. García-Antón. The effect of temperature on the galvanic corrosion of the copper/AISI 304 pair in $\mathrm{LiBr}$ solutions under hydrodynamic conditions, Corros. Sci. 52 (2010) 722-733. 
[38] R. Leiva-García, M. J. Muñoz-Portero, J. García-Antón. Corrosion behaviour of sensitized and unsensitized Alloy 900 (UNS 1.4462) in concentrated aqueous lithium bromide solutions at different temperatures, Corros. Sci. 52 (2010) 950-959.

[39] V. Guiñón-Pina, A. Igual-Muñoz, J. García-Antón. Influence of pH on the electrochemical behaviour of a duplex stainless steel in highly concentrated LiBr solutions, Corros. Sci. 53 (2011) 575-581.

[40] R. M. Fernández-Domene, E. Blasco-Tamarit, D. M. García-García, J. GarcíaAntón. Repassivation of the damage generated by cavitation on UNS N08031 in a LiBr solution by means of electrochemical techniques and Confocal Laser Scanning Microscopy, Corros. Sci. 52 (2010) 3453-3464.

[41] M. Kaneko, H. S. Isaacs. Pitting of stainless steel in bromide, chloride and bromide/chloride solutions, Corros. Sci. 42 (2000) 67-78.

[42] E. Blasco-Tamarit, A. Igual-Muñoz, J. García-Antón, D. García-García. Effect of temperature on the corrosion resistance and pitting behaviour of Alloy 31 in LiBr solutions, Corros. Sci. 50 (2008) 1848-1857.

[43] J. Sikora, E. Sikora, D. D. Macdonald. The electronic structure of the passive film on tungsten, Electrochim. Acta 45 (2000) 1875-1883.

[44] K. Park, S. Ahn, H. Kwon. Effects of solution temperature on the kinetic nature of passive film on Ni, Electrochim. Acta 56 (2011) 1662-1669.

[45] Z. Jiang, X. Dai, H. Middleton. Investigation on passivity of titanium under steady-state conditions in acidic solutions, Mater. Chem. Phys. 126 (2011) 859-865.

[46] A. Igual-Muñoz, J. García-Antón, J. L. Guiñón, V. Pérez-Herranz. Effects of solution temperature on localized corrosion of high nickel content stainless steels and nickel in chromated LiBr solution, Corros. Sci. 48 (2006) 33493374.

[47] M. Kaneko, H. S. Isaacs. Effects of molybdenum on the pitting of ferritic- and austenitic-stainless steels in bromide and chloride solutions, Corros. Sci. 44 (2002) 1825-1834.

[48] H. J. Jang, H. S. Kwon. In situ study on the effects of Ni and Mo on the passive film formed on $\mathrm{Fe}-20 \mathrm{Cr}$ alloys by photoelectrochemical and MottSchottky techniques, J. Electroanal. Chem. 590 (2006) 120-125.

[49] J. D. Fritz, Effects of Metallurgical Variables on the Corrosion of Stainless Steels, in: S.D. Cramer, B.S. Covino, Jr. (Eds.), Corrosion: Fundamentals, Testing and Protection, Vol. 13A, ASM Handbook, in: 2003, 266-274.

[50] D. D. Macdonald. The Point Defect Model for the Passive State, J. Electrochem. Soc. 139 (1992) 3434-3449. 
[51] E. Sikora, D. D. Macdonald. Defining the passive state, Solid State Ionics 94 (1997) 141-150.

[52] D. D. Macdonald. Passivity - the key to our metals-based civilization, Pure Appl. Chem. 71 (1999) 951-978.

[53] D. D. Macdonald. The history of the Point Defect Model for the passive state: A brief review of film growth aspects, Electrochim. Acta 56 (2011) 17611772 .

[54] J. Amri, T. Souier, B. Malki, B. Baroux. Effect of the final annealing of cold rolled stainless steels sheets on the electronic properties and pit nucleation resistance of passive films, Corros. Sci. 50 (2008) 431-435.

[55] M. Bojinov. The ability of a surface charge approach to describe barrier film growth on tungsten in acidic solutions, Electrochim. Acta 42 (1997) 34893498 .

[56] S. J. Ahn, H. S. Kwon. Effects of solution temperature on electronic properties of passive film formed on $\mathrm{Fe}$ in $\mathrm{pH} 8.5$ borate buffer solution, Electrochim. Acta 49 (2004) 3347-3353.

[57] L. Hamadou, A. Kadri, N. Benbrahim. Characterisation of passive films formed on low carbon steel in borate buffer solution ( $\mathrm{pH} 9.2)$ by electrochemical impedance spectroscopy, Appl. Surf. Sci. 252 (2005) 15101519 .

[58] S. Modiano, C. S. Fugivara, A. V. Benedetti. Effect of citrate ions on the electrochemical behaviour of low-carbon steel in borate buffer solutions, Corros. Sci. 46 (2004) 529-545.

[59] M. Bojinov, T. Laitinen, K. Mäkelä, T. Saario. Conduction Mechanism of the Passive Film on Iron Based on Contact Electric Impedance and Resistance Measurements, J. Electrochem. Soc. 148 (2001) B243-B250.

[60] Y. Zhang, D. D. Macdonald, M. Urquidi-Macdonald, G. R. Engelhardt, R. B. Dooley. Passivity breakdown on AISI Type 403 stainless steel in chloridecontaining borate buffer solution, Corros. Sci. 48 (2006) 3812-3823.

[61] J. Huang, X. Wu, E. H. Han. Electrochemical properties and growth mechanism of passive films on Alloy 690 in high-temperature alkaline environments, Corros. Sci. 52 (2010) 3444-3452.

[62] M. J. Carmezim, A. M. P. Simoes, M. F. Montemor, M. Da Cunha Belo. Capacitance behaviour of passive films on ferritic and austenitic stainless steel, Corros. Sci. 47 (2005) 581-591.

[63] Z. Feng, X. Cheng, C. Dong, L. Xu, X. Li. Passivity of 316L stainless steel in borate buffer solution studied by Mott-Schottky analysis, atomic absorption spectrometry and X-ray photoelectron spectroscopy, Corros. Sci. 52 (2010) 3646-3653. 
[64] T. L. S. L. Wijesinghe, D. J. Blackwood. Electrochemical and Photoelectrochemical Characterization of the Passive Film Formed on AISI 254SMO Super-Austenitic Stainless Steel, J. Electrochem. Soc. 154 (2007) C16-C23.

[65] C. Y. Chao, L. F. Lin, D. D. Macdonald. A Point Defect Model for Anodic Passive Films, J. Electrochem. Soc. 128 (1981) 1187-1194.

[66] B. Beverskog, I. Puigdomenech. Pourbaix Diagrams for the Ternary System of Iron-Chromium-Nickel, CORROSION 55 (1999) 1077-1087.

[67] M. Da Cunha Belo, M. Walls, N. E. Hakiki, J. Corset, E. Picquenard, G. Sagon, D. Noël. Composition, structure and properties of the oxide films formed on the stainless steel 316L in a primary type PWR environment, Corros. Sci. 40 (1998) 447-463.

[68] C. Marconnet, Y. Wouters, F. Miserque, C. Dagbert, J. P. Petit, A. Galerie, D. Féron. Chemical composition and electronic structure of the passive layer formed on stainless steels in a glucose-oxidase solution, Electrochim. Acta 54 (2008) 123-132.

[69] I. Olefjord, B.-O. Elfstrom. The Composition of the Surface During Passivation of Stainless Steels, CORROSION 38 (1982) 46-52.

[70] M. F. Montemor, A. M. P. Simoes, M. G. S. Ferreira, M. D. C. Belo. The role of Mo in the chemical composition and semiconductive behaviour of oxide films formed on stainless steels, Corros. Sci. 41 (1999) 17-34.

[71] M. F. Montemor, M. G. S. Ferreira, N. E. Hakiki, M. Da Cunha Belo. Chemical composition and electronic structure of the oxide films formed on 316L stainless steel and nickel based alloys in high temperature aqueous environments, Corros. Sci. 42 (2000) 1635-1650.

[72] M. Da Cunha Belo, N. E. Hakiki, M. G. S. Ferreira. Semiconducting properties of passive films formed on nickel-base alloys type Alloy 600: influence of the alloying elements, Electrochim. Acta 44 (1999) 2473-2481.

[73] T. Dan, T. Shoji, Z. Lu, K. Sakaguchi, J. Wang, E. H. Han, W. Ke. Effects of hydrogen on the anodic behavior of Alloy 690 at $60^{\circ}$ C, Corros. Sci. 52 (2010) 1228-1236.

[74] R. J. Lemire, G. A. McRae. The corrosion of Alloy 690 in high-temperature aqueous media - thermodynamic considerations, J. Nucl. Mater. 294 (2001) 141-147.

[75] Y. H. Hou and. Structural, electronic and magnetic properties of partially inverse spinel $\mathrm{CoFe}_{2} \mathrm{O}_{4}$ : a first-principles study, J. Phys. D: Appl. Phys. 43 (2010) 445003 (7pp).

[76] S. H. Lee, S. J. Yoon, G. J. Lee, H. S. Kim, C. H. Yo, K. Ahn, D. H. Lee, K. H. Kim. Electrical and magnetic properties of $\mathrm{NiCr}_{\mathrm{x}} \mathrm{Fe}_{2-\mathrm{x}} \mathrm{O}_{4}$ spinel $(0<\mathrm{x}<0.6)$, Mater. Chem. Phys. 61 (1999) 147-152. 
[77] L. Wegrelius, F. Falkenberg, I. Olefjord. Passivation of Stainless Steels in Hydrochloric Acid, J. Electrochem. Soc. 146 (1999) 1397-1406.

[78] A. C. Lloyd, J. J. Noël, S. McIntyre, D. W. Shoesmith. Cr, Mo and W alloying additions in Ni and their effect on passivity, Electrochim. Acta 49 (2004) 3015-3027.

[79] M. Uemura, T. Yamamoto, K. Fushimi, Y. Aoki, K. Shimizu, H. Habazaki. Depth profile analysis of thin passive films on stainless steel by glow discharge optical emission spectroscopy, Corros. Sci. 51 (2009) 1554-1559.

[80] N. Padhy, R. Paul, U. Kamachi Mudali, B. Raj. Morphological and compositional analysis of passive film on austenitic stainless steel in nitric acid medium, Appl. Surf. Sci. 257 (2011) 5088-5097.

[81] C. Sunseri, S. Piazza, F. Di Quarto. Photocurrent Spectroscopic Investigations of Passive Films on Chromium, J. Electrochem. Soc. 137 (1990) 2411-2416.

[82] M. Urquidi-Macdonald, D. D. Macdonald. Theoretical Analysis of the Effects of Alloying Elements on Distribution Functions of Passivity Breakdown, J. Electrochem. Soc. 136 (1989) 961-967.

[83] L. Pons, M. L. Délia, R. Basséguy, A. Bergel. Effect of the semi-conductive properties of the passive layer on the current provided by stainless steel microbial cathodes, Electrochim. Acta 56 (2011) 2682-2688.

\section{$\underline{\text { Tables captions }}$}

Table 1. Compositions of the different steels used in this study (in wt.\%).

Table 2. Values of the pitting potential, $E_{p}$, and the PREN for the six steels studied in this work.

Table 3. Acceptor and donor densities for the six steels in the $992 \mathrm{~g} / \mathrm{l} \mathrm{LiBr}$ solution at $25{ }^{\circ} \mathrm{C}$, at film formation potentials of $-300 \mathrm{mV}_{\mathrm{Ag} / \mathrm{AgCl}}$ and $100 \mathrm{mV}_{\mathrm{Ag} / \mathrm{AgCl}}$.

$\underline{\text { Figures captions }}$

Figure 1. Potentiodynamic polarisation curves for the six steels studied in the $992 \mathrm{~g} / \mathrm{l} \mathrm{LiBr}$ solution at $25^{\circ} \mathrm{C}$. 
Figure 2. (a) Mott-Schottky plots for the films formed on the six steels at the passive potential of $-300 \mathrm{mV} \mathrm{Ag} / \mathrm{AgCl}_{\text {; }}$ (b) Mott-Schottky plots for the films formed on the steels with lower alloy element content (carbon steel, AISI 430, AISI 304 and AISI 316) at the same passive potential; (c) comparison between Mott-Schottky plots for the passive films formed on Alloy 33 and Alloy 31 at $-300 \mathrm{mV} \mathrm{Ag}_{\mathrm{AgCl}}$ and at $100 \mathrm{mV}$ Ag/AgCl .

Figure 3. Schematic representation of the composition and electronic structure of the passive films formed on: (a) AISI 430, AISI 304 and AISI 316 at potentials within the passive range, (b) Alloy 33 and Alloy 31 at low passive potentials and (c) Alloy 33 and Alloy 31 at high passive potentials. For AISI 316 and Alloy 31, Mo species will also be present in the passive films. Note that the different layers are not in scale. 


\begin{tabular}{|c|c|c|c|c|c|c|c|c|c|c|c|}
\hline Steel & Description & $\mathbf{C}$ & $\mathrm{Cr}$ & $\mathbf{N i}$ & Mo & $\mathbf{S i}$ & $\mathbf{P}$ & $\mathbf{C u}$ & $\mathbf{N}$ & $\mathbf{S}$ & $\mathbf{F e}$ \\
\hline S355J2G3 & Carbon Steel & 0.24 & ----- & ---- & ----- & ----- & ----- & ----- & ---- & ----- & bal. \\
\hline AISI 430 & Ferritic SS & 0.07 & 17 & ----- & ----- & $<1$ & $<0.04$ & ----- & ----- & $<0.03$ & bal. \\
\hline AISI 304 & Austenitic SS & 0.05 & 18 & 10 & ----- & $<0.8$ & ----- & ----- & 0.1 & ----- & bal. \\
\hline AISI 316 & Austenitic SS & 0.05 & 17 & 11 & 2.3 & $<0.8$ & $<0.04$ & ----- & 0.1 & $<0.03$ & bal. \\
\hline $\begin{array}{l}\text { Alloy } 33 \\
\text { (UNS R20033) }\end{array}$ & Superaustenitic SS & 0.015 & 32.8 & 30.9 & 1.7 & 0.3 & 0.01 & 0.6 & 0.4 & $<0.01$ & bal. \\
\hline $\begin{array}{l}\text { Alloy } 31 \\
\text { (UNS N08031) }\end{array}$ & Superaustenitic SS & 0.015 & 26.7 & 31.8 & 6.6 & 0.1 & 0.02 & 1.2 & 0.2 & $<0.01$ & bal. \\
\hline
\end{tabular}




\begin{tabular}{|l|c|c|}
\hline Steel & PREN & $E_{p}(\mathrm{Ag} / \mathrm{AgCl}) / \mathrm{mV}$ \\
\hline S355J2G3 & 0 & $-190 \pm 9$ \\
\hline AISI 430 & 17 & $204 \pm 26$ \\
\hline AISI 304 & 21 & $264 \pm 8$ \\
\hline AISI 316 & 27.59 & $394 \pm 23$ \\
\hline Alloy 33 & 50.41 & $482 \pm 15$ \\
\hline Alloy 31 & 54.48 & $533 \pm 11$ \\
\hline
\end{tabular}




\begin{tabular}{|l|c|c|c|c|}
\hline \multirow{2}{*}{ Steel } & \multicolumn{2}{|c|}{$-\mathbf{3 0 0} \mathbf{~} \mathbf{V}$} & \multicolumn{2}{c|}{$100 \mathbf{~} \mathbf{V}$} \\
\cline { 2 - 5 } & $N_{\boldsymbol{D}} / \mathbf{1 0}^{\mathbf{2 0}} \mathbf{c m}^{\mathbf{- 3}}$ & $\boldsymbol{N}_{\boldsymbol{A}} / \mathbf{1 0}^{\mathbf{2 0}} \mathbf{c m}^{\mathbf{- 3}}$ & $N_{\boldsymbol{D}} / \mathbf{1 0}^{\mathbf{2 0}} \mathbf{c m}^{\mathbf{- 3}}$ & $\boldsymbol{N}_{\boldsymbol{A}} / \mathbf{1 0}^{\mathbf{2 0}} \mathbf{c m}^{-\mathbf{3}}$ \\
\hline S355J2G3 & $21.1 \pm 0.6$ & ----- & ----- & ----- \\
\hline AISI 430 & $11.3 \pm 0.4$ & $21 \pm 2$ & ----- & ----- \\
\hline AISI 304 & $11.3 \pm 0.2$ & $24 \pm 4$ & ----- & ----- \\
\hline AISI 316 & $9.6 \pm 0.3$ & $22 \pm 4$ & ----- & ----- \\
\hline Alloy 33 & $6.2 \pm 0.4$ & $29 \pm 5$ & $5.2 \pm 0.2$ & $6.3 \pm 0.4$ \\
\hline Alloy 31 & $4.5 \pm 0.2$ & ----- & $5.1 \pm 0.2$ & $4.5 \pm 0.3$ \\
\hline
\end{tabular}


Click here to download Figures (if any): Figure 1.doc

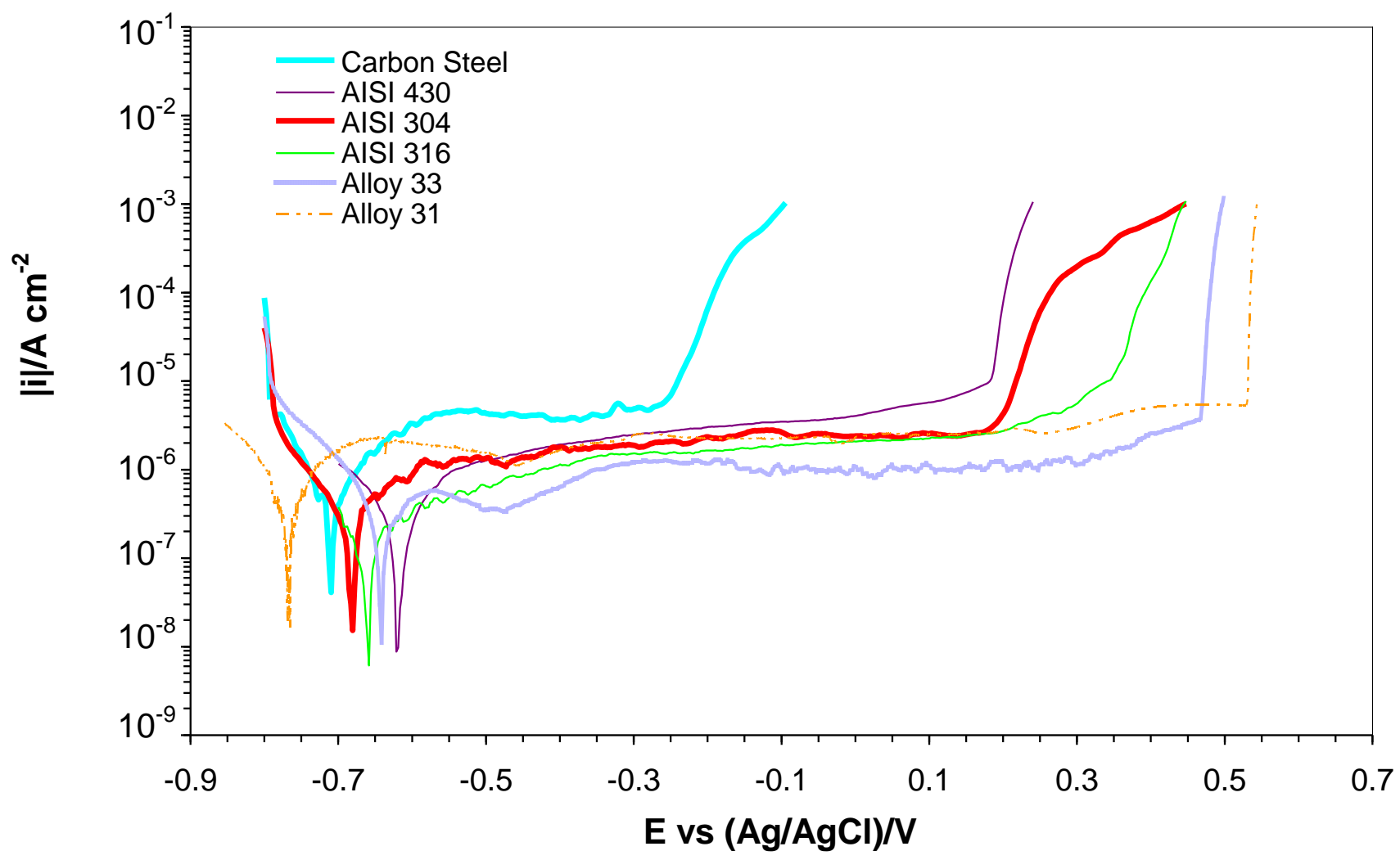




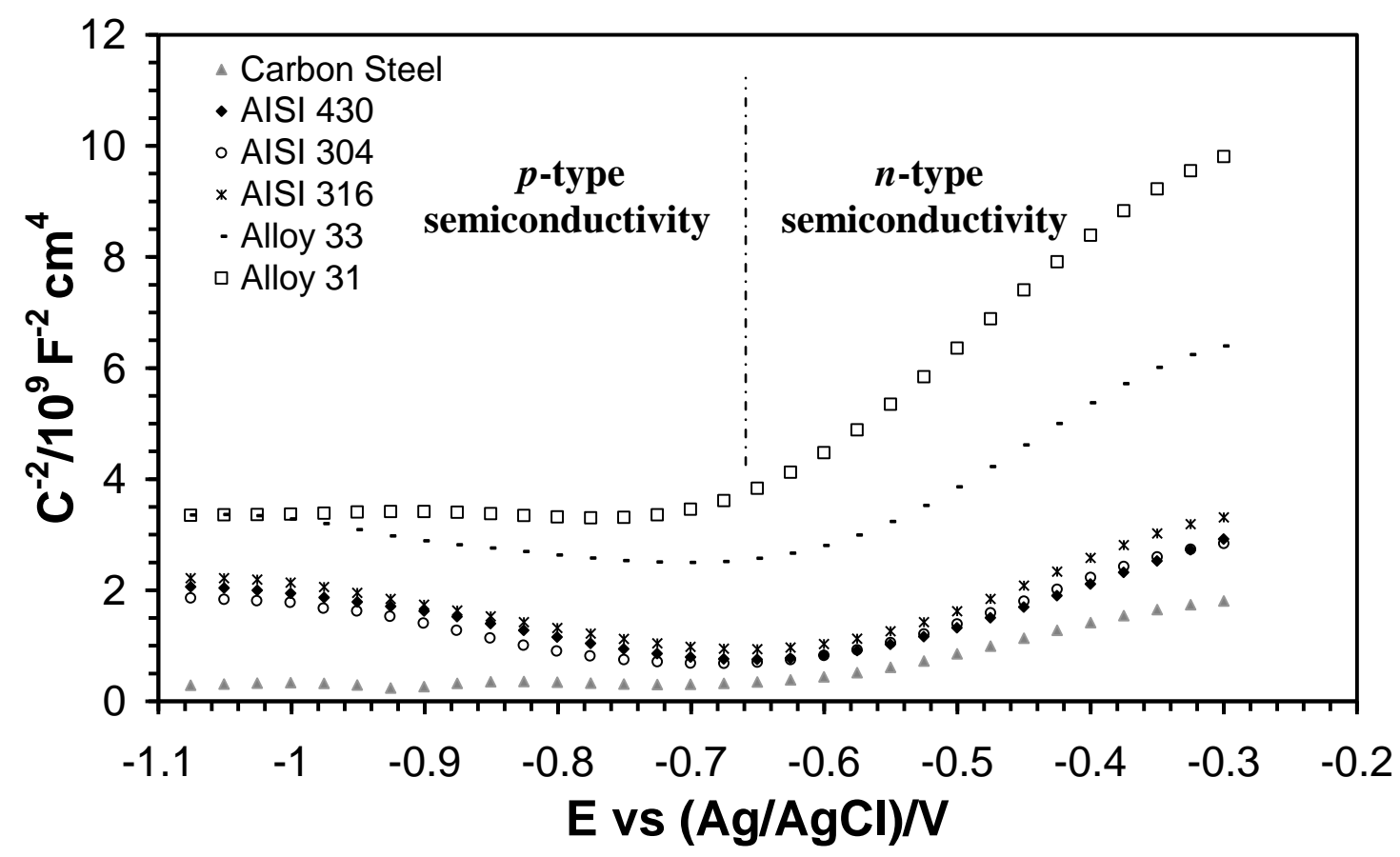

(a)

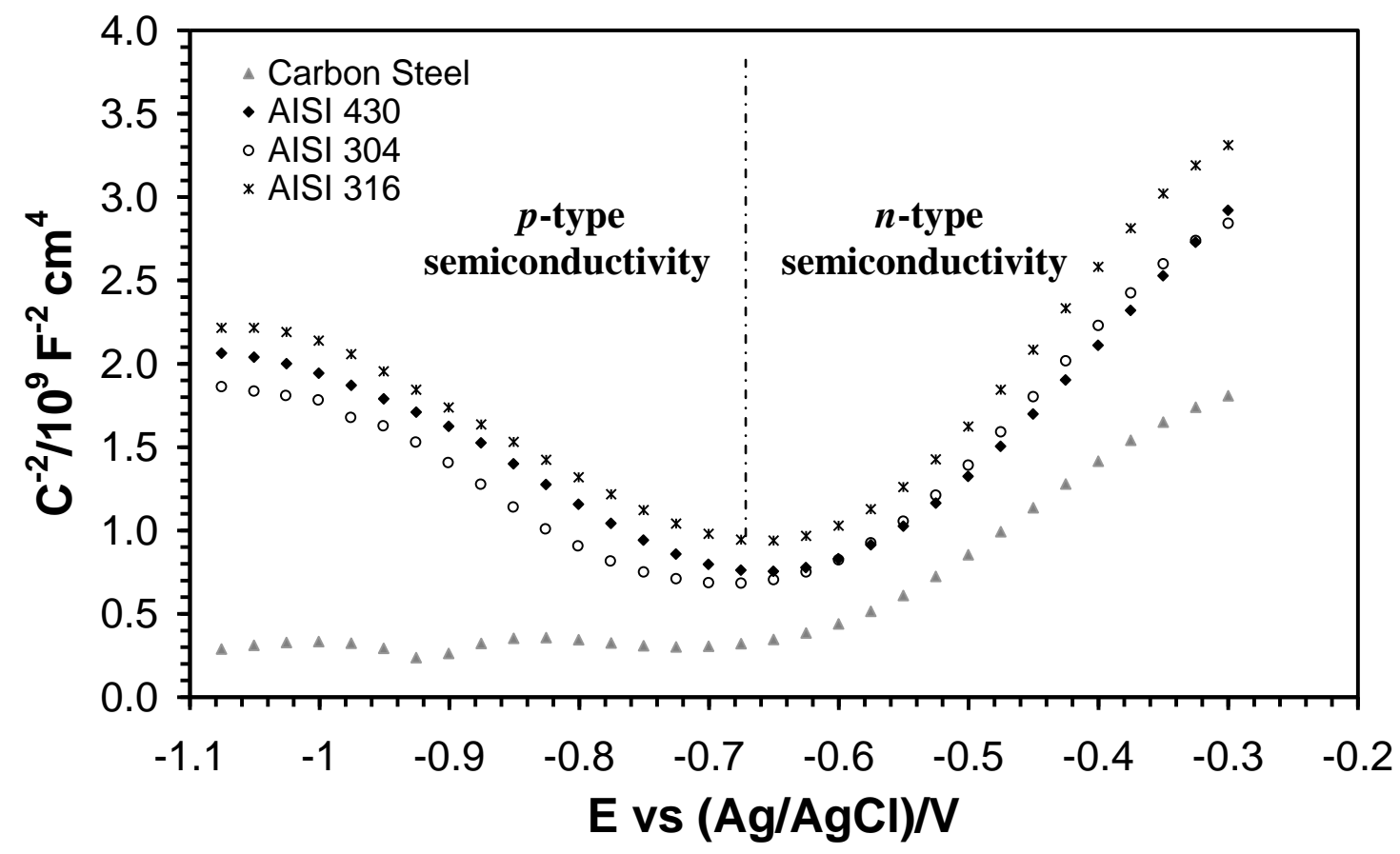

(b) 


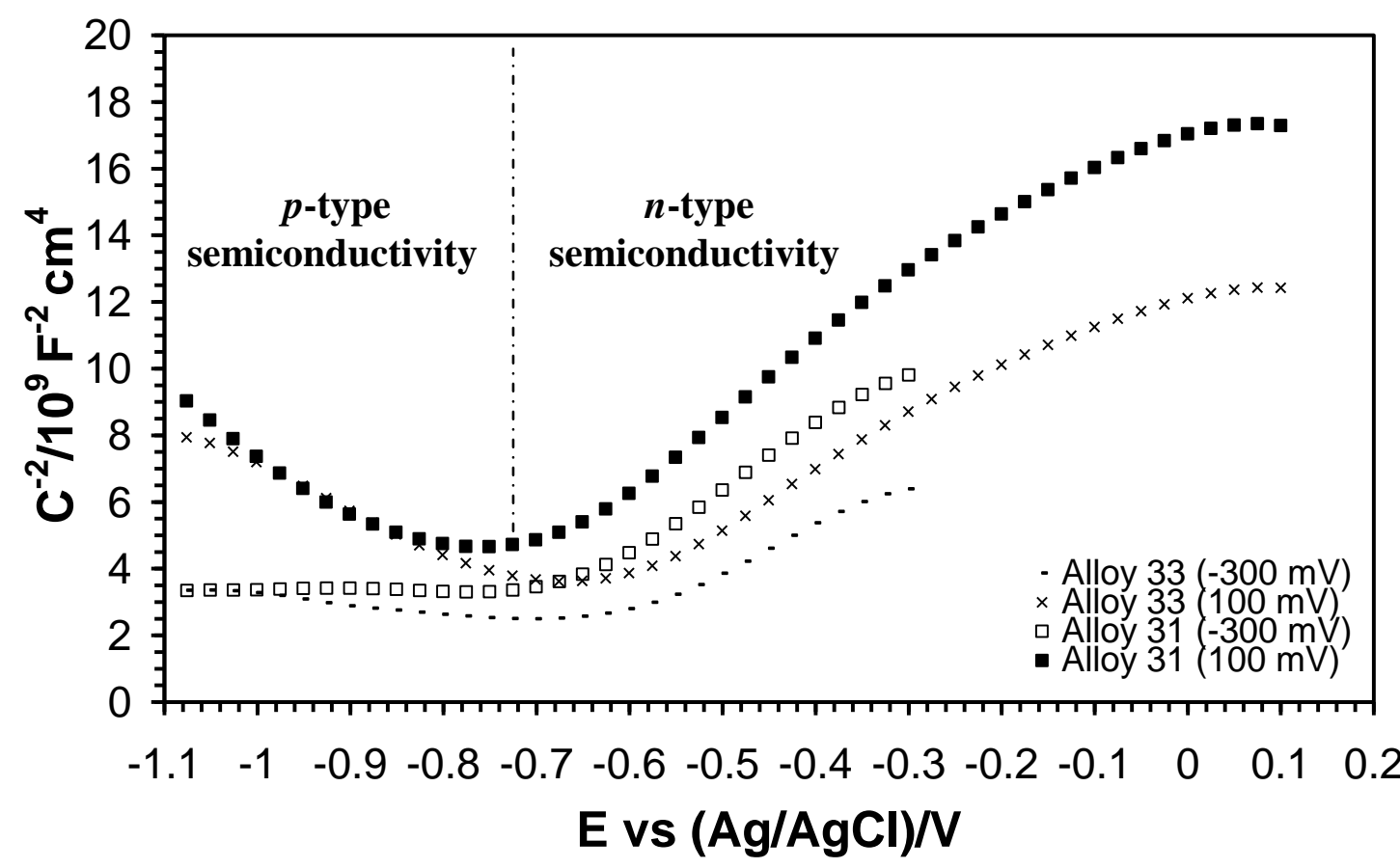

(c) 
(a)

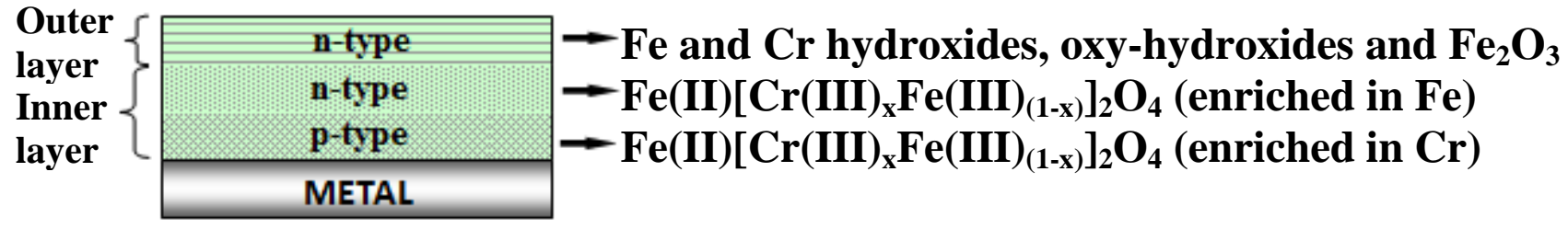

(b)

Outer $\left\{\longdiv { \square \text { n-type } } \rightarrow\right.$ Fe and $\mathrm{Cr}$ hydroxides, oxy-hydroxides and $\mathrm{Fe}_{2} \mathrm{O}_{3}$

Inner layer

n-type METAL

(c)

\begin{tabular}{|c|c|c|}
\hline \multirow[t]{2}{*}{$\left.\begin{array}{l}\text { Outer } \\
\text { layer } \\
\text { Inner } \\
\text { layer }\end{array}\right\}$} & $\begin{array}{l}\text { n-type } \\
\text { n-type } \\
\text { p-type }\end{array}$ & \multirow[t]{2}{*}{$\begin{array}{l}\rightarrow \mathrm{Fe} \text { and } \mathrm{Cr} \text { hydroxides, oxy-hydroxides and } \mathrm{Fe}_{2} \mathrm{O}_{3} \\
\rightarrow \mathrm{Ni}(\mathrm{II})\left[\mathrm{Fe}(\mathrm{III})_{\mathrm{y}} \mathrm{Cr}(\mathrm{III})_{(1-\mathrm{y})}\right]_{2} \mathrm{O}_{4}(\text { enriched in } \mathrm{Fe}) \\
\rightarrow \mathrm{Ni}(\mathrm{II})\left[\mathrm{Fe}(\mathrm{III})_{\mathrm{y}} \mathrm{Cr}(\mathrm{III})_{(1-\mathrm{y})}\right]_{2} \mathrm{O}_{4}(\text { enriched in } \mathrm{Cr})\end{array}$} \\
\hline & METAL & \\
\hline
\end{tabular}

